\title{
BUSINESS ENVIRONMENT QUALITY INDEX IN THE SME SEGMENT
}

\author{
- Martin Cepel, Andrius Stasiukynas, Anna Kotaskova, Jan Dvorsky
}

\begin{abstract}
The aim of this paper was to define and quantify significant factors that shape the quality of the business environment in the SME segment and to create the business environment quality index. A part of this aim was a comparison of defined factors in the Czech Republic (CR) and the Slovak Republic (SR). In regards to the aim defined, a survey-based research was conducted with enterprises operating in the SME segment. 312 enterprises in CR and 329 enterprises in SR were approached during this research. To verify the defined scientific hypotheses, a custom Business Environment Quality Index was created that was quantified separately for CR and SR. The research results brought interesting findings. The aggregated Business Environment Quality Index in the Slovak Republic reached the value of 0.460, which was higher than that of the Czech Republic (0.418). Slovak entrepreneurs gave the economic factors a higher rating than Czech entrepreneurs. Similarly, Slovak entrepreneurs rated the importance of the Central Bank in establishing a stable business environment and the role of commercial banks in financing business needs more positively. The evaluation of political factors is relatively negative in both countries. Slovak entrepreneurs evaluated more positively the judicial system in the area of commercial law, the state's influence on the business environment, and the administrative burden on enterprises. Czech entrepreneurs had a minor issue with the state bureaucracy's impact on the business environment. The evaluation of technological factors is relatively negative in both countries, as the value of this index is slightly below 0.250 . Slovak entrepreneurs better assessed the situation on the job market and the cooperation of the public sector with the business environment. On the contrary, Czech entrepreneurs gave the infrastructure level in the area of research and development a better rating. The evaluation of social factors is relatively positive in both countries. Entrepreneurs in the Slovak Republic perceive a more positive attitude of the society towards entrepreneurs and a more intense influence of the family on entrepreneurship, and positively evaluate media's activities in regards to the business environment. The evaluation of the competitive environment is more positive in Slovakia. When evaluating the narrower competitive environment, it was discovered that Slovak entrepreneurs think that customers, suppliers, and employees play a positive role in their business.
\end{abstract}

Keywords: business environment, quality of business environment, quality index

JEL Classification: L126

\section{INTRODUCTION}

Entrepreneurship is a significant part of the economic system of every country, having important effects on the growth of the entire society. Therefore, many authors put emphasis on the role of small and medium-sized enterprises (SMEs) in the effective functioning of an economic 
system (Dobeš et al., 2017; Ključnikov \& Popesko, 2017; Kozubíková et al., 2017; Vrchota \& Rehor, 2017; Virglerova et al., 2016; Czarniewski, 2016; Belas et al., 2015; Kot, 2017).

Small and medium-sized enterprises face strong competition, but have many new opportunities for growth at the same time (Chládková, 2015; Kljucnikov \& Belas, 2016; Adamowicz \& Machla, 2016; Ivanová, 2017). According to Bunoa et al. (2015), the quality of business environment creates basic conditions for the growth of small and medium-sized enterprises (SMEs), and its gradual improvement is the best way to support SMEs and motivate people to start a business.

This paper examines important factors of the quality of business environment and quantifies their significance in the Czech Republic and Slovakia. The originality of this research lies in the definition and quantification of the factors shaping the quality of the business environment in the SME sector, as well as the comparison of business conditions in both countries.

The structure of the research is the following: The theoretical part presents the research results on the quality of the business environment. The second part defines the aim of the research, the methodology, and the descriptions of the data used. The third part presents the research results and discussion about the issue. The conclusion offers a final summary of the research.

\section{THEORETICAL PART}

The quality of the business environment is a key factor for countries' economic growth. "Best practices" support the effective functioning on the market and motivate the enterprises' business activities. The quality of the business environment is significant for the economy's competitiveness growth and for its future sustainability (Wruuck, 2015, Bunoa et al., 2015; Pietrzak et al., 2017; Kaur \& Srivastava, 2017; Petrenko et al., 2107; Armas-Cruz et al., 2017). When entrepreneurs and enterprises are successful, the entire economy thrives, the unemployment rate decreases, and the population's standard of living increases (Chládková, 2015).

The quality of the business environment is a frequently used term in the professional, political, and entrepreneurial sphere, with many synonyms available (Chládková, 2015).

According to Bunoa et al. (2015), the business environment within an enterprise comprises economic, political, institutional, legal, technological, and cultural conditions that enable and shape the enterprises' business activities (Ohanyan \& Androniceanu, 2017; Gavurova et al., 2016). Chládková (2015) states that the business environment is influenced by a wide spectrum of conditions in the area of legislature, institutional infrastructure (Draskovic et al., 2017; Lakic \& Draskovic, 2015), and market operations.

Macroeconomic factors play an important role in the context of shaping the business environment (Sinicakova \& Gavurova, 2017). Bekeris (2012) argues that macroeconomic factors are important determinants of the business conditions in the country, and hence, these factors can have a significant impact on the profitability of enterprises. According to Dragnic (2014), macroeconomic slowdown has an utmost effect on the business condition of the firms. He found that the lack of demand for products had a negative effect on the growth of SMEs. The paper shows that SMEs faced high competition from unregistered SMEs, which was causing a problem for SMEs to sell products to their target customers. 
The state regulating entrepreneurship also plays an important role. In this context, Artistovnik \& Obadic (2015) found that high start-up costs for businesses can have a negative impact on the development of SMEs, as it can discourage any potential individual to become an entrepreneur. Second, they showed that lengthy processes for preparing the business registration documents discourage the development of SMEs. It was also discovered that government legislation processes and strict rules and regulations hinder the growth of SMEs and also initiate the SME owners to engage in corruption and illegal ways of processing business documents. High tax burden and difficulties in preparing the tax related documents slow the development of SMEs (Sanusi et al., 2017). On the other hand, they also found that high quality of government bureaucracy or efficient government policy can enhance the performance of SMEs and also increase the output of the SMEs in terms of their utilized resources.

Kitching et al. (2015) state that regulation is one of the most dynamic conditions for SMEs which creates opportunities as well as barriers for firms. Overall, the authors argue that regulation could be beneficial for the large firms, but it creates problems for the smaller one's s due to their high compliance costs.

According to Marinescu \& Jora (2013), excessive cost of the legislation process needed for SME business registration reduce the efficiency of SMEs and also their productivity. These extra costs are increasing the operational costs of the firms and limiting the SMEs' competitiveness on the market. They also find that due to corruption, it is difficult to enforce the protection of property rights which is a barrier for the entrepreneur to engage in business activities. The paper also finds that corruption is badly affecting opening any businesses, as it has a negative effect on the motivation of potential entrepreneurs. It is also highlighted that corruption is reducing the economic outcome of the SMEs, since SMEs need to spend their earnings on corrupted activities and hence reduce the profit margin from the businesses.

On the other hand, Banno et al. (2014) state that government financial support can help the SMEs to expand their activities outside of their domestic market which helps to improve the economic conditions of the firms. Business environment in the Czech Republic is strongly influenced by firms' innovation performance (Zizlavsky, 2016).

Ahmedova (2015) states that access to finance is the most important factor for SMEs to be competitive on the market. Business with sufficient external sources can innovate and invest, which enables them to be more successful in the competitive environment.

Tonoyan et al. (2010) found that when banks and other money lenders do not provide finance with less paper work, entrepreneurs usually engage in corrupted activities to get the financial support in transition countries. They also show that due to complex rules and regulations, entrepreneurs in the transition countries are engaging in corruption to boost their business activities which is not common in the developed countries. They also find that extreme bureaucracy and complex bank loan paper work is driving the entrepreneurs to engage in providing bribes and corrupted activities which is creating barriers for easy access to bank finance.

According to Marinescu (2013), a recent scientific research examining institutional basics of economic performance proves that institutions protecting ownership rights and decreasing transaction costs are crucial for the country's economic performance. The institutional quality of the business 
environment comprises eight institutional factors: 1. protection of ownership rights; 2. easy access to entrepreneurship; 3. good enforceability of the law; 4. reasonable tax burden; 5. reasonable regulatory burden; 6. license acquisition; 7. corruption; 8. institutional limitations in entrepreneurship and investment. Innovation barriers that limit firms' innovation performance are financial/organizational constraints and external factors - market size and its saturation, big and strong companies with well-established market position as well as regulation (Rajh \& Božić, 2016).

Conorto et al. (2014) present a complex characteristic of factors determining the quality of the business environment. The authors define three significant areas of the business environment: a broader business environment, a competitive environment, and a narrower business environment. The broader business environment comprises factors on the macroeconomic level that exist regardless of the existence or the rank of individual entrepreneurial subjects. These are economic factors, technological factors, and social factors. Economic factors are the result of the character and the orientation of the country's economy, while the economic environment influences the changes of the material, energy, financial, investment and information conditions. The economic factors include areas such as inflation tendencies, evolution of the interest rate, general availability of loans and other means of financing an enterprise, population's money saving and money spending tendency, etc. The political stability and the political orientation of the country in which the enterprise operates are of a great importance for entrepreneurial subjects. The political factors define the legal conditions and regulate the business environment. The politicallegal environment creates a legislative and support frame for entrepreneurial activities, regulates international business relations, the tax and levy politics, the anti-monopoly politics, the stability of the legal environment, the effectivity of the judicial system, the enforceability of the law, the administrative burden on enterprises, etc. Technological factors are mainly the availability of human capital and the infrastructure in the field of research and development, and the cooperation of the public sector with the private sector, etc. The social factors can be considered quite marginal, they only affect the business environment indirectly - these are values, opinions, and lifestyles of the people in the environment, and the evolution of population, cultural, ecological, demographic, religious, and ethnic conditions (Androniceanu, 2017). The broader economic environment is characteristic for its nearly identical influence on all entrepreneurial subjects, and its improvement or deterioration has a direct impact on the quality of the business environment. The competitive environment comprises barriers to entry, buyer power, supplier power, threat of substitution, and competitive rivalry (the concept of Porter's five forces). The narrower business environment includes direct competitors, customers, suppliers, and employees.

Detailed information on the quality of the business environment as a whole and its individual attributes are offered by a number of indexes, such as: the Global Competitiveness Index, the Index of Economic Freedom, the Corruption Perception Index and others that constitute the method of multicriterial evaluation of the country's competitiveness (Belanová, 2014).

Körner et al. (2002) classify business environment quality indexes on basis of index constructs (unique and composite indexes), character of the data used (subjective and objective indexes), and data sources (external experts and local entrepreneurs). Given this context, the authors state that almost all indicators used to measure the quality of the business environment are subjective, as it is impossible to rate an entire array of aspects using objective data. 
These indexes, given their focus, creation methodology, defined rating scales, and the way data are acquired (Slovak Entrepreneurs' Alliance 2017; Slovak Entrepreneurs' Alliance 2015) cannot sufficiently and precisely evaluate the SMEs' quality of the business environment in the context of respective countries, and do not fully reflect the opinions of the very people involved in the business environment, namely the entrepreneurs themselves.

\section{AIM, METHODOLOGY, AND DATA}

The aim of this paper was to define and quantify significant factors that shape the quality of the business environment in the SME segment and to create the business environment quality index. A part of this aim was a comparison of defined factors in the Czech and the Slovak Republic.

In regards to the defined aim, a survey-based research was conducted with enterprises operating in the SME segment. 312 enterprises in CR and 329 enterprises in SR were approached during this research. Data collection took place in 2018. The method of random choice using the "Randbetween" mathematical function was used to select enterprises from the "Albertína" database comprising enterprises in the Czech Republic. Slovak enterprises were randomly selected from the "Cribis" database containing the list of enterprises, organizations, and entrepreneurs. The enterprises were approached via email asking them to fill out the online questionnaire. The questionnaire was intended for business owners or top management (hereinafter entrepreneurs).

The response rate in the Czech Republic was approximately $4 \%$ (out of over 7800 enterprises). The number of approached enterprises in the Slovak Republic was more than 9400, and the response rate was approximately $3.5 \%$.

The structure of respondents within the Czech Republic (312 enterprises) was the following: by county: Zlínsky kraj 49 enterprises, Ustecký kraj 27 enterprises, Stredočeský kraj 14 enterprises, Plzeňský kraj 22 enterprises, Pardubický kraj 17 enterprises, Olomoucký kraj 26 enterprises, Moravskoslezký kraj 17 enterprises, Liberecký kraj 28 enterprises, Královéhradecký kraj 17 enterprises, Kraj Vysočina 25 enterprises, Karlovarský kraj 15 enterprises, Jihomoravský kraj 22 enterprises, Jihočeský kraj 16 enterprises, and Hlavné mesto Praha 17 enterprises. Business area: services 109 enterprises, retail 73 enterprises, manufacturing 53 enterprises, construction 29 enterprises, agriculture 9 enterprises, transportation 19 enterprises, other business area 23 enterprises. Time period of operating a business: 56 enterprises $1-5$ years, 48 enterprises 5 - 10 years, 208 enterprises more than 10 years. Size of business: 258 micro-enterprises (up to 10 employees), 43 small enterprises (up to 50 employees), and 11 medium-sized enterprises (up to 250 employees). Highest attained education level of the entrepreneur: 50 high school without diploma, 135 high school with diploma, and 127 college education. Gender of entrepreneurs: 236 men, 76 women.

The structure of respondents within the Slovak Republic (329 enterprises) was the following: by county: Prešovský kraj 76 enterprises, Košický kraj 75 enterprises, Bratislavský kraj 56 enterprises, Banskobystrický kraj 30 enterprises, Žilinský kraj 28 enterprises, Trnavský kraj 27 enterprises, Trenčiansky kraj 20 enterprises, and Nitriansky kraj 17 enterprises. Business area: services 122 enterprises, retail 69 enterprises, manufacturing 51 enterprises, construction 39 enterprises, 
agriculture 20 enterprises, transportation 11 enterprises, other business area 17 enterprises. Time period of operating a business: 104 enterprises $1-5$ years, 78 enterprises 5 - 10 years, and 147 enterprises more than 10 years. Size of business: 234 micro-enterprises (up to 10 employees), 71 small enterprises (up to 50 employees), and 24 medium-sized enterprises (up to 250 employees). Highest attained education level of the entrepreneur: 10 high school without diploma, 95 high school with diploma, and 224 college education. Gender of entrepreneurs: 251 men, 78 women.

In accordance with the approach by Conorto et al. (2014), individual constructs were defined using the following statements which are also the factors influencing university students' propensity for entrepreneurship:

\section{Economic factors: (EF)}

\section{EF1: Macroeconomic environment:}

EF11: I consider the macroeconomic environment of my country to be favorable for doing business.

EF12: The state of macroeconomic environment of my country supports starting a business.

EF13: The present macroeconomic environment supports enterprises' innovation activities.

EF14: The present level of basic macroeconomic factors (GDP, employment, inflation) supports business and creates interesting business opportunities.

\section{EF2: Monetary policy and interest rates}

EF21: The Central Bank's monetary policy has a positive impact on the business environment.

EF22: Banks' interest rates have a positive impact on the business environment.

EF23: Banks' interest rates have a positive impact on enterprises' innovation activities.

EF24: The Central Bank's monetary policy stabilizes the business environment.

\section{EF3: Financing enterprises:}

EF31: Enterprises have easy access to bank loans.

EF32: Banks' credit conditions for entrepreneurs are acceptable.

EF33: The cost of loans for enterprises is acceptable.

EF34: Banks have a positive impact on the quality of the business environment.

EF4 Population consumption, changes in income and the structure of consumer expenditure

EF41: The growing consumer consumption positively influences the quality of the business environment.

EF42: People can afford to buy more products and services.

EF43: The growing consumer consumption positively impacts my business.

EF44: People purchase more, compared to the past. 


\section{Political factors: (PF)}

\section{PF1: Legal environment}

PF11: I positively rate the level of legislature in business.

PF12: The judicial system in the area of business law works well.

PF13: The enforceability of law in my country is good.

PF14: The legal environment in my country is stable.

\section{PF2: State regulation and support of entrepreneurship}

PF21: The state's tax and levy policy supports entrepreneurship.

PF22: The state politics supports the export of our products and services.

PF23: The state supports entrepreneurship financially.

PF24: The state has a positive impact on the quality of business environment.

\section{PF3: State bureaucracy}

PF31: The administrative burden on businesses is adequate.

PF32: The administrative burden on entrepreneurs has decreased in the past five years.

PF33: The state bureaucracy does not negatively influence the business environment.

PF34: the state bureaucracy does not influence entrepreneurship.

\section{PF4: Quality of education}

PF41: I view university education as that of a high quality.

PF42: I view high school education as that of a high quality.

PF43: The state is able to provide a qualified work force for businesses.

PF44: Graduates have high quality knowledge and skills.

\section{Technological factors (TF)}

\section{TF1: Availability of human capital}

TF11: High schools yield high quality graduates who prove to be valuable assets for the business sector.

TF12: High schools supply a sufficient number of high quality graduates for business needs.

TF13: Universities yield high quality graduates who prove to be valuable assets for the business sector.

TF14: There is a sufficient amount of qualified work force on the job market that proves to be a valuable asset for the business sector.

\section{TF2: Infrastructure in the area of research and development}

TF21: The infrastructure in the area of research and development is well established in my country. 
TF22: The level of state's support of research and development in my country is high.

TF23: Results of research and development help entrepreneurs in my country.

TF24: State's support of research and development has a growing trend.

TF3: Cooperation of the private and the public sector

TF31: The level of cooperation between the private and the public sector is high.

TF32: The public sector offers entrepreneurs a high quality service.

TF33: The cooperation of enterprises with the public sector has a positive impact on the business environment.

TF34: The cooperation of the private sector and the public sector has a growing trend.

\section{Social factors (SF)}

\section{SF1: Entrepreneurs' views and evaluation of the social environment}

SF11: Our society appreciates entrepreneurs.

SF12: Politicians and the public correctly understand how entrepreneurs contribute to the society.

SF13: My close environment (family, friends, acquaintances) support me in doing business.

SF14: Good business practices help shape the quality of business environment.

\section{SF2: Family environment}

SF21: The family environment motivates people to start a business.

SF22: It is easier to do business if close relatives are in business.

SF23: I acquired many skills in my family that help me in my business.

SF24: My family helps me in my business.

\section{SF3: Media and communication environment}

SF31: Media (television, broadcast, and other media) truthfully inform about entrepreneurship.

SF32: Media help shape the quality of business environment using presentations of goof business practices.

SF33: Media adequately inform about the business environment.

SF34: Media support entrepreneurs' communication with the public.

\section{SF4: Entrepreneurs' social stance}

SF41: The advantages of doing business outnumber the disadvantages.

SF42: An entrepreneur is wealthier and has a higher social status.

SF43: Entrepreneurship enables a better career growth and leads to interesting work opportunities. 
SF44: Conducting business allows for a full utilization of one's skills.

\section{SF5: Entrepreneurs' emotional stance}

SF51: If I were to decide whether to start a business today, I would do it again.

SF52: I am able to bear the risk associated with entrepreneurship in a normal way.

SF53: I feel that the society appreciates me and my work.

SF54: I feel inner satisfaction with the fact that I am conducting business.

\section{Competitive environment (CF)}

CF11: New competitors entering the industry I operate in present an adequate risk.

CF12: The level of competition in the industry I operate in is normal.

CF13: My customers accept the prices of my products and services.

CF14: My suppliers' prices for products and services are adequate.

\section{Narrower business environment (FF) comprises direct competitors, customers, suppliers, and employees.}

FF11: My competitors do not present a threat to my business.

FF12: My customers support me in doing business.

FF13: My suppliers intensively support me in doing business.

FF14: My employees intensively help me in achieving business goals.

\section{Y: The quality of business environment (QBE)}

QBE1: The business environment of my country is of good quality and convenient for starting a business.

QBE2: The business environment of my country bears adequate risk and enables to start a business.

QBE3: Conditions for doing business have improved in my country in the last five years.

QBE4: The business environment in my country is suitable for starting a business.

Individual factors were incorporated into the survey by a random selection in order to achieve the highest possible objectivity level.

In order to quantify and compare important factors determining the quality of the business environment of the SME segment, an aggregated index of the quality of business environment was created. It can be characterized as the average/mean value of the positive evaluation of individual factors:

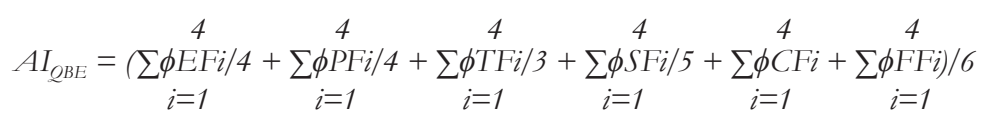


where:

$A I_{Q B E}$ - aggregated index of the business environment,

$\phi E F i, \phi P F i, \phi T F i, \phi S F i, \phi C F i, \phi F F i$ - average/mean value of the positive evaluation of individual constructs integrated into aggregated index.

Simultaneously, a partial index of the quality of business environment $\left(P_{Q B E}\right)$ was created, which can be calculated as the average value of positive answers to the respective QBE factors:

$$
\text { PIQBE }=\underset{i=1}{\substack{4 \\ i=1}}
$$

In theory, the following should be true: $A I_{Q B E}=P I_{Q B E}$. It means that the evaluation of important factors determining the quality of the business environment should equal the direct evaluation of the quality of business environment. If the difference between the given indexes is less than $10 \%$, it can be said that this model has a good predicative potential.

The evaluation of indexes: the interval of 0.001 to 0.250 : the value is low, interval of 0.251 to 0.500 : the value is below average; interval of 0.501 to 0.750 : the value is above average, index value of over 0.750 is high.

When developing this paper, three scientific hypotheses were established:

H1: The aggregated index of the quality of business environment in CR will be below average (lower than 0.501).

H2: The aggregated index of the quality of business environment in SR will be below average (lower than 0.501).

H3: There are no statistically significant differences in the evaluation of individual factors of the quality of business environment by Czech and Slovak enterprises.

H4: The difference between the aggregated and the partial index of the quality of business environment will be lower than $10 \%$ in both the Czech and the Slovak Republic.

To evaluate $\mathrm{H} 1, \mathrm{H} 2$, and $\mathrm{H} 4$, the method of descriptive statistics was used: indexes.

To evaluate H3, the Z score method was used. Statistically significant differences between positive answers of the designated social groups were compared through Pearson statistics at the significance level of $5 \%$. If the calculated p-value was lower than $5 \%$, the null hypothesis was rejected and the alternative hypothesis was adopted. The calculations were made using free software available at ttp://www.socscistatistics.com/tests/ztest/Default2.aspx.

\section{RESULTS AND DISCUSSION}

The research results are listed in the tables below. 
Tab. 1 - Evaluation of factors in the economic area (EF) in CR and SR. Source: own calculation

\begin{tabular}{|l|l|l|l|l|l|}
\hline Factor & $\begin{array}{l}\text { Ratio of positive } \\
\text { answers expressed } \\
\text { by index CR/SR }\end{array}$ & $\begin{array}{l}\text { Z-score } \\
\text { p-value } \\
\text { CR/SR }\end{array}$ & Factor & $\begin{array}{l}\text { Ratio of positive } \\
\text { answers expressed } \\
\text { by index CR/SR }\end{array}$ & $\begin{array}{l}\text { Z-score } \\
\text {-value }\end{array}$ \\
\hline EF11 & $0.324 / 0.271$ & 0.142 & EF21 & $\mathbf{0 . 2 4 7 / 0 . 3 3 7}$ & $\mathbf{0 . 0 1 2}$ \\
\hline EF12 & $0.247 / 0.246$ & 0.984 & EF22 & $0.343 / 0.407$ & 0.093 \\
\hline EF13 & $0.260 / 0.271$ & 0.435 & EF23 & $\mathbf{0 . 2 6 9 / 0 . 3 6 2}$ & $\mathbf{0 . 0 1 1}$ \\
\hline EF14 & $0.317 / 0.380$ & 0.097 & EF24 & $\mathbf{0 . 2 4 0 / 0 . 3 4 7}$ & $\mathbf{0 . 0 0 3}$ \\
\hline Index EF1 & $0.287 / 0.292$ & & Index EF2 & $0.275 / 0.363$ & \\
\hline EF31 & $0.452 / 0.495$ & 0.271 & EF41 & $0.660 / 0.650$ & 0.795 \\
\hline EF32 & $0.356 / 0.386$ & 0.429 & EF42 & $0.827 / 0.821$ & 0.834 \\
\hline EF33 & $\mathbf{0 . 3 6 5 / 0 . 4 4 7}$ & $\mathbf{0 . 0 3 6}$ & EF43 & $0.631 / 0.669$ & 0.322 \\
\hline EF34 & $\mathbf{0 . 2 4 0 / 0 . 3 5 0}$ & $\mathbf{0 . 0 0 3}$ & EF44 & $0.808 / 0.827$ & 0.535 \\
\hline Index EF3 & $0.353 / 0.420$ & & $\begin{array}{l}\text { Index EF4 } \\
\text { Index EF }\end{array}$ & $0.732 / 0.742$ & $0.412 / 0.454$ \\
\hline
\end{tabular}

The results in Table 1 indicate that Slovak entrepreneurs rated the economic factors more positively than the Czech entrepreneurs (Index EF/SR $=0.455$; Index EF/CR $=0.412$. Partial indexes EF1, EF2, EF3, and EF4 were rated similarly.

Statistically significant differences in positive answers were discovered in factors EF21, EF23, and EF24 (evaluation of the monetary policy) and in EF33 and EF34 (evaluation of commercial banks' impact on the business sector). Slovak entrepreneurs more positively rated the role of the Central Bank in creating a stable business environment, as well as the role of commercial banks in financing business needs.

Tab. 2 - Evaluation of political factors (PF) in CR and SR. Source: own calculation

\begin{tabular}{|l|l|l|l|l|l|}
\hline Factor & $\begin{array}{l}\text { Ratio of positive } \\
\text { answers expressed by } \\
\text { index CR/SR }\end{array}$ & $\begin{array}{l}\text { Z-score } \\
\text { p-value }\end{array}$ & Factor & $\begin{array}{l}\text { Ratio of positive } \\
\text { answers expressed } \\
\text { by index CR/SR }\end{array}$ & $\begin{array}{l}\text { Z-score } \\
\text { p-value }\end{array}$ \\
\hline PF11 & $0.154 / 0.201$ & 0.121 & PF21 & $0.077 / 0.091$ & 0.516 \\
\hline PF12 & $0.109 / 0.188$ & $\mathbf{0 . 0 0 5}$ & PF22 & $0.301 / 0.307$ & 0.873 \\
\hline PF13 & $0.144 / 0.155$ & 0.704 & PF23 & $0.112 / 0.155$ & 0.112 \\
\hline PF14 & $0.183 / 0.240$ & 0.075 & PF24 & $0.106 / 0.161$ & $\mathbf{0 . 0 4 0}$ \\
\hline Index PF1 & $0.148 / 0.196$ & & Index PF2 & $0.149 / 0.166$ & \\
\hline PF31 & $0.119 / 0.222$ & $<\mathbf{0 . 0 0 1}$ & PF41 & $0.413 / 0.353$ & 0.112 \\
\hline PF32 & $0.058 / 0.164$ & $<\mathbf{0 . 0 0 1}$ & PF42 & $0.324 / 0.295$ & 0.429 \\
\hline PF33 & $0.413 / 0.213$ & $<\mathbf{0 . 0 0 1}$ & PF43 & $0.099 / 0.173$ & $\mathbf{0 . 0 0 6}$ \\
\hline PF34 & $0.324 / 0.116$ & $<\mathbf{0 . 0 0 1}$ & PF44 & $0.244 / 0.231$ & 0.712 \\
\hline Index PF3 & $0.229 / 0.179$ & & $\begin{array}{l}\text { Index PF4 } \\
\text { Index PF }\end{array}$ & $\begin{array}{l}0.270 / 0.263 \\
\mathbf{0 . 1 9 9 / 0 . 2 0 1}\end{array}$ & \\
\hline
\end{tabular}


The results in Table 2 indicate that the evaluation of political factors is relatively negative in both countries, as the value of this index is at approximately 0.250 . Slovak entrepreneurs rated the political factors more positively in comparison with Czech entrepreneurs (Index PF/SR $=0.201$; Index EF/CR = 0.199). Partial indexes PF1 and PF2 were rated similarly. Indexes PF3 and PF4 reached a higher value in the Czech Republic.

Statistically significant differences in positive answers were discovered in factors PF12, PF24, PF31, PF32, PF33, PF34, and PF43. Slovak entrepreneurs more positively rated the judicial system in the area of commercial law, the state's impact on the business environment, and the administrative burden on enterprises. Czech entrepreneurs had a minor issue with the impact of state bureaucracy on the business environment.

Tab. 3 - Evaluation of technological factors (TF) in CR and SR. Source: own calculation

\begin{tabular}{|l|l|l|l|l|l|}
\hline Factor & $\begin{array}{l}\text { Ratio of positive } \\
\text { answers expressed } \\
\text { by index CR/SR }\end{array}$ & $\begin{array}{l}\text { Z-score } \\
\text { p-value }\end{array}$ & Factor & $\begin{array}{l}\text { Ratio of positive } \\
\text { answers expressed } \\
\text { by index CR/SR }\end{array}$ & $\begin{array}{l}\text { Z-score } \\
\text { p-value }\end{array}$ \\
\hline TF11 & $0.224 / 0.243$ & 0.575 & TF21 & $0.231 / 0.137$ & $\mathbf{0 . 0 0 2}$ \\
\hline TF12 & $0.183 / 0.207$ & 0.441 & TF22 & $0.208 / 0.173$ & 0.258 \\
\hline TF13 & $0.317 / 0.313$ & 0.904 & TF23 & $0.279 / 0.264$ & 0.682 \\
\hline TF14 & $0.170 / 0.295$ & $<\mathbf{0 . 0 0 1}$ & TF24 & $0.218 / 0.277$ & 0.085 \\
\hline Index TF1 & $0.224 / 0.264$ & & Index TF2 & $0.234 / 0.213$ & \\
\hline TF31 & $0.179 / 0.176$ & 0.912 & TF33 & $0.263 / 0.371$ & $\mathbf{0 . 0 0 3}$ \\
\hline TF32 & $0.103 / 0.161$ & $\mathbf{0 . 0 4 2}$ & TF34 & $0.196 / 0.322$ & $<\mathbf{0 . 0 0 1}$ \\
\hline $\begin{array}{l}\text { Index TF3 } \\
\text { Index TF }\end{array}$ & $\begin{array}{l}0.185 / 0.258 \\
\mathbf{0 . 2 1 4 / 0 . 2 4 5}\end{array}$ & & & & \\
\hline
\end{tabular}

The evaluation of technological factors is relatively negative in both countries, as the value of this index is slightly above 0.250 . Slovak entrepreneurs more positively rated the technological factors compared to Czech entrepreneurs (Index PF/SR =0,245; Index EF/CR =0.214). Partial indexes FF1 and TF3 were rated similarly. Index TF2 reached a higher value in the Czech Republic.

Statistically significant differences in positive answers were discovered in factors TF14, TF21, TF32, TF33, and TF34. Slovak entrepreneurs more positively rated the situation on the job market and the cooperation of the public sector with the business environment. Czech entrepreneurs, on the contrary, gave the level of infrastructure in the area of research and development a better rating.

Tab. 4 - Evaluation of social factors (SF) in CR and SR. Source: own calculation

\begin{tabular}{|l|l|l|l|l|l|}
\hline Factor & $\begin{array}{l}\text { Ratio of positive } \\
\text { answers expressed by } \\
\text { index CR/SR }\end{array}$ & $\begin{array}{l}\text { Z-score } \\
\text { p-value }\end{array}$ & Factor & $\begin{array}{l}\text { Ratio of positive } \\
\text { answers expressed } \\
\text { by index CR/SR }\end{array}$ & $\begin{array}{l}\text { Z-score } \\
\text { p-value }\end{array}$ \\
\hline SF11 & $0.199 / 0.280$ & $\mathbf{0 . 0 0 3}$ & SF21 & $0.545 / 0.620$ & $<\mathbf{0 . 0 0 1}$ \\
\hline
\end{tabular}




\begin{tabular}{|l|l|l|l|l|l|}
\hline SF12 & $0.090 / 0.155$ & $<\mathbf{0 . 0 0 1}$ & SF22 & $0.657 / 0.729$ & $\mathbf{0 . 0 4 7}$ \\
\hline SF13 & $0.827 / 0.821$ & 0.833 & SF23 & $0.542 / 0.687$ & $<\mathbf{0 . 0 0 1}$ \\
\hline SF14 & $0.503 / 0.657$ & $<\mathbf{0 . 0 0 1}$ & SF24 & $0.817 / 0.796$ & 0.503 \\
\hline Index SF1 & $0.405 / 0.478$ & & Index SF2 & $0.640 / 0.708$ & \\
\hline SF31 & $0.170 / 0.252$ & $\mathbf{0 . 0 1 1}$ & SF41 & $0.503 / 0.520$ & 0.674 \\
\hline SF32 & $0.199 / 0.331$ & $<\mathbf{0 . 0 0 1}$ & SF42 & $0.301 / 0.356$ & 0.144 \\
\hline SF33 & $0.276 / 0.337$ & 0.091 & SF43 & $0.603 / 0.726$ & 0.952 \\
\hline SF34 & $0.208 / 0.392$ & $<\mathbf{0 . 0 0 1}$ & SF44 & $0.846 / 0.845$ & 0.968 \\
\hline Index SF3 & $0.213 / 0.328$ & & Index SF4 & $0.563 / 0.614$ & \\
\hline SF51 & $0.660 / 0.748$ & 0.015 & SF53 & $0.333 / 0.505$ & $<\mathbf{0 . 0 0 1}$ \\
\hline SF52 & $0.683 / 0.720$ & 0.298 & SF54 & $0.731 / 0.799$ & $\mathbf{0 . 0 4 0}$ \\
\hline $\begin{array}{l}\text { Index SF5 } \\
\text { Index SF }\end{array}$ & $\begin{array}{l}0.602 / 0.693 \\
\mathbf{0 . 4 8 5} / \mathbf{0 . 5 6 4}\end{array}$ & & & & \\
\hline
\end{tabular}

The evaluation of social factors (Table 4) is relatively positive in both countries, as the value of this index is between 0.485 and 0.564 . Slovak entrepreneurs rated social factors better than their Czech counterparts (Index PF/SR $=0.564$; Index EF/CR $=0.485$. Partial indexes SF1, SF2, SF3, SF4, and SF5 were rated similarly.

Statistically, entrepreneurs in the Slovak Republic perceive a more positive attitude of the society towards entrepreneurs and a more intense influence of the family on entrepreneurship, and positively evaluate media's activities in regards to the business environment.

Tab. 5 - Evaluation of factors (CF and FF) in CR and SR. Source: own processing

\begin{tabular}{|l|l|l|l|l|l|}
\hline Factor & $\begin{array}{l}\text { Ratio of positive } \\
\text { answers expressed } \\
\text { by index CR/SR }\end{array}$ & $\begin{array}{l}\text { Z-score } \\
\text { p-value }\end{array}$ & Factor & $\begin{array}{l}\text { Ratio of positive } \\
\text { answers expressed by } \\
\text { index CR/SR }\end{array}$ & $\begin{array}{l}\text { Z-score } \\
\text { p-value }\end{array}$ \\
\hline CF11 & $0.644 / 0.647$ & 0.936 & FF11 & $0.410 / 0.401$ & 0.818 \\
\hline CF12 & $0.641 / 0.660$ & 0.624 & FF12 & $0.625 / 0.717$ & $\mathbf{0 . 0 1 3}$ \\
\hline CF13 & $0.760 / 0.787$ & 0.401 & FF13 & $0.497 / 0.614$ & $\mathbf{0 . 0 0 3}$ \\
\hline CF14 & $0.619 / 0.693$ & $\mathbf{0 . 0 4 8}$ & FF14 & $0.590 / 0.666$ & $\mathbf{0 . 0 4 7}$ \\
\hline Index CF & $0.666 / 0.697$ & & Index FF & $0.530 / 0.600$ & \\
\hline
\end{tabular}

The evaluation of the competitive environment is more positive in Slovakia. A statistically significant difference was discovered in the evaluation of the suppliers' pricing policy ( $\mathrm{p}$-value $=$ 0.048).

When evaluating the narrower competitive environment, it was discovered that statistically, Slovak entrepreneurs think that customers, suppliers, and employees play a positive role in their business activities. 
Tab. 6 - Evaluation of the quality of business environment in CR and SR. Source: own calculation

\begin{tabular}{|l|l|l|}
\hline Factor & Ratio of positive answers expressed by index CR/SR & $\begin{array}{l}\text { Z-score } \\
\text { p-value }\end{array}$ \\
\hline QBE1 & $0.253 / 0.195$ & 0.075 \\
\hline QBE2 & $0.561 / 0.526$ & 0.373 \\
\hline QBE3 & $\mathbf{0 . 2 1 2 / 0 . 2 9 8}$ & $\mathbf{0 . 0 1 2}$ \\
\hline QBE4 & $0.333 / 0.356$ & 0.555 \\
\hline Index QBE & $0.340 / 0.343$ & \\
\hline
\end{tabular}

Table 6 indicates that Slovak entrepreneurs rated the quality of the business environment slightly more positively. QBE3 yielded statistically significant differences, which indicates that Slovak entrepreneurs see a recent improvement in the business conditions.

Based on the research results, an aggregated and a partial index of the quality of the business environment in CR and SR were quantified:

$$
\begin{aligned}
& A I_{Q B E / C R}=0.412+0.199+0.214+0.485+0.666+0.530 / 6=0.418 \\
& P I_{Q B E / C R}=0.340 \\
& A I_{Q B E / C R} \text { does not equal } P I_{Q B E / C R} \\
& A I_{Q B E / S R}=0.460 \\
& P I_{Q B E / S R}=0.343 \\
& A I_{Q B E / S R} \text { does not equal } P I_{Q B E / S R}
\end{aligned}
$$

The aggregated index of the quality of business environment reached the value of 0.418 in the Czech Republic. This can mean that the average value of the positive ratings of factors determining the quality of the business environment reached the value of $41.8 \%$. The partial index of the quality of business environment reached the value of 0.360 in the Czech Republic.

It is interesting to see that the value of the aggregated index is higher than that of the partial index (difference of $7.8 \%$ ).

The aggregated index of the quality of business environment reached the value of 0.460 in Slovakia. This can mean that the average value of the positive ratings of factors determining the quality of the business environment reached the value of $46 \%$. The partial index of the quality of business environment reached the value 0.343 in Slovakia.

It is interesting to see that the value of the aggregated index is higher than that of the partial index (difference of $12 \%$ ).

$H 1$ was confirmed. The aggregated index of the quality of business environment in CR was lower than 0.501 .

H2 was confirmed. The aggregated index of the quality of business environment in SR was lower than 0.501 .

H3 was not confirmed. Statistically significant differences were discovered in the evaluation of individual factors. 
H4 was not confirmed. The difference between the aggregated index of the business environment and the partial index of the quality of business environment in Slovakia was higher than $10 \%$.

The presented results indicate that the presented model used for the evaluation of the quality of business environment is of adequate quality, as the difference between the aggregated index value and the partial index value oscillates around $10 \%$.

It is interesting to see that the value of the aggregated index is higher than that of the partial index in both countries. This may be explained by the fact that the value of the aggregated index is influenced by extreme values in the model used: the lowest index value was recorded in the evaluation of political factors and the highest in the evaluation of the SMEs' competitiveness factor. Based on the calculations, the negative impact of political factors in evaluating the quality of the business environment outweighs the positive perception of other competitiveness factors of SMEs such as the competitive environment factors.

The index of the evaluation of political factors reached the lowest value. The research results imply that Czech entrepreneurs view the administrative burden on enterprises as an issue, as it has not decreased in the past years. According to Virglerová et al. (2016), it was discovered during the examination of the administrative burden and the perception of its development in the Czech Republic that only $11.13 \%$ of entrepreneurs agree with the statement that administrative burden associated with entrepreneurship was reduced in the last 5 years. Server Podnikatel.cz (2013) offers similar findings, stating that the majority of entrepreneurs spend entire days filling out forms. They even think bureaucracy is growing. The vast majority of entrepreneurs think that statements about decreasing the administrative burden are mere words. According to $59 \%$ of the entrepreneurs, the bureaucratic burden has only been increasing in the past years.

In the Slovak Republic, the evaluation of the state's support of entrepreneurship via tax and levy policy reached the lowest value.

The highest index values were noted in the evaluation of the competitive environment in CF13 and EF12. Entrepreneurs in both countries provided a high index value when evaluating the role customers play in their business. The entrepreneurs were satisfied with the fact that customers accept the price of their products (76\% in CR and $78.7 \%$ in SR) and expressed a strong belief that their customers support them in their business (62.5\% in CR and $71.7 \%$ in SR). This trend is probably influenced by the development of the macroeconomic environment in both countries, with the growing GDP supporting both supply and demand.

Based on the information from Investiční web (2016), the Czech Republic was placed 31st in the global evaluation of competitiveness. The best results in CR were achieved in: macroeconomic environment (ranked 19th globally), basic education (ranked 25th globally), higher education (ranked 27th), and financial markets (ranked 27th). Relatively weakest results were achieved in CR in the following categories institutions (ranked 54th), market size (ranked 46th), and the effectiveness of the job market (ranked 44th). The Czech Republic lags behind the EU15 countries average in the key pillars of innovation and the quality of the business environment. At the same time, the Czech Republic was placed higher than the EU 15 average in the macroeconomic environment and financial markets pillars. 
In 2017, Slovakia moved up significantly on the competitiveness scale that the World Economic Forum in Switzerland (WEF) creates on the basis of key economic data and research among managers (currently ranking 59th globally, which represents a 6-rank shift compared to the previous year). The overall score changed from 4.28 to 4.33 which can also be attributed to some steps made by the state aiming at the simplification of entrepreneurship and decreasing the administrative burden. In reality, this improvement can be attributed to a higher number of mobile lines, higher average Internet speed, or a higher number of airlines. Slovakia's largest problem within entrepreneurship is traditionally corruption and unnecessary bureaucracy on the second place, which bothers managers even more than the tax rates. Tax and levy laws, job market, and insufficient education of the workforce were also subject of complaint (Slovak Entrepreneurs' Alliance, 2017).

The results of the research are partially compatible with the data published by the WEF, as they yielded a relatively positive evaluation of the macroeconomic factors in both countries (a positive evaluation of the economic development, development of the financial market, adequate demand for products and services, etc.). However, despite the Czech Republic's better ranking on the WEF scale, the Slovak entrepreneurs rated the condition of the business environment better than their Czech counterparts.

\section{CONCLUSION}

The aim of this paper was to define and quantify significant factors that shape the quality of the business environment in the SME segment and to create the business environment quality index. A part of this aim was a comparison of the factors defined in the Czech Republic and the Slovak Republic.

The aggregated Business Environment Quality Index in the Slovak Republic reached the value of 0.460, which was higher than that of the Czech Republic (0.418).

Slovak entrepreneurs gave the economic factors a higher rating than Czech entrepreneurs. Similarly, Slovak entrepreneurs rated the importance of the Central Bank in establishing a stable business environment and the role of commercial banks in financing business needs more positively.

The evaluation of political factors is relatively negative in both countries, as the value of this index was at the level of approximately 0.250 . Slovak entrepreneurs considered the political factors more positively than Czech entrepreneurs. Slovak entrepreneurs evaluated more positively the judicial system in the area of commercial law, the state's influence on the business environment, and the administrative burden on enterprises. Czech entrepreneurs had a minor issue with the state bureaucracy's impact on the business environment.

The evaluation of technological factors is relatively negative in both countries, as the value of this index is slightly below 0.250 . Slovak entrepreneurs better assessed the situation on the job market and the cooperation of the public sector with the business environment. On the contrary, Czech entrepreneurs gave the infrastructure level in the area of research and development a better rating. 
The evaluation of social factors is relatively positive in both countries, as the value of this index was between 0.485 and 0.564 . Entrepreneurs in the Slovak Republic perceive a more positive attitude of the society towards entrepreneurs and a more intense influence of the family on entrepreneurship, and positively evaluate media's activities in regards to the business environment.

The evaluation of the competitive environment is more positive in Slovakia. When evaluating the narrower competitive environment, it was discovered that Slovak entrepreneurs think that customers, suppliers, and employees play a positive role in their business.

The research has its limitations, but also brought interesting findings and a potential inspiration for further research on the quality of the business environment in the SME segment.

\section{References}

1. Adamowicz, M., \& Machla, A. (2016). Small and medium enterprises and the support policy of local government. Oeconomia Copernicana, 7(3), 405-437. https://doi.org/10.12775/ OeC.2016.024.

2. Ahmedova, S. (2015). Factors for increasing competitiveness of small and medium-sized enterprises (SMEs) in Bulgaria. Procedia-Social and Behavioral Sciences, 195 (1), 1104-1112.

3. Androniceanu, A. (2017). Hospital management based on the relationship between doctors and patients. Administratie si Management Public, (29), 41-53.

4. Armas-Cruz, Y, Gil-Soto, E., Oreja-Rodríguez, J. R. (2017) Environmental management in SMEs: organizational and sectoral determinants in the context of an Outermost European Region. Journal of Business Economics and Management, 18(5), 935-953, https://doi.org/10.3846/ 16111699.2017.1373375.

5. Artistovnik, A. \& Obadic, A. (2015). The impact and efficiency of public administrative excellence on fostering SMEs in the EU countries. Amfiteatru Economic, 17(39), 761-774.

6. Banno, M., Piscitello, L., \& Varum, C. (2014). The impact of public support on SMEs outward FDI: Evidence from Italy. Journal of Small Business Management, 52(1), 22-38.

7. Bekeris, R. (2012). The impact of macro-economic indicators upon SME's profitability. Ekonomika, 91(3), 117-128.

8. Belanová, K. (2014). Komparácia kvality podnikatel'ského prostredia v krajinách Vyšehradskej štvorky s osobitným akcentom na dostupnost' finančných zdrojov. Biatec, 22(1): 12-17.

9. Belas, J., Kljucnikov, A., Vojtovic, S., \& Sobekova-Májkova, M. (2015). Approach of the SME Entrepreneurs to Financial Risk Management in Relation to Gender and Level of Education. Economics and Sociology, 8 (4), 32-42.

10. Božić, L. \& Rajh, E. (2016). The factors constraining innovation performance of SMEs in Croatia. Economic Research-Ekonomska Istraživanja, 29(1), 314-324, https://doi.org/10.1080/ 1331677X.2016.1168040.

11. Bunoa, M., Nadanyiova, M., \& Hraskova, D. (2015). The comparison of the quality of business environment in the countries of Visegrad group. Procedia Economics and Finance, 26 (1), 423-430. 
12. Conorto, R. a kol. (2014). Analýza, monitor kvality podnikatel'ského prostredia v SR a konkurencie schopnost' ekonomiky. Bratislava: Centrum vzdelávania MPSVR SR.

13. Czarniewski, S. (2016). Small and Medium-Sized Enterprises in the Context of Innovation and Entrepreneurship in the Economy. Polish Journal of Management Studies, 13(1), 30-39.

14. Dobeš, K., Kot, S., Kramoliš, J., \& Sopková, G. (2017). The Perception of Governmental Support in the Context of Competitiveness of SMEs in the Czech Republic. Journal of Competitiveness, 9 (3), 34-50. https://doi.org/10.7441/joc.2017.03.03.

15. Dragnic, D. (2014). Impact of internal and external factors on the performance of fastgrowing small and medium businesses. Management: Journal of Contemporary Management Issues, 19(1), 119-159.

16. Draskovic, V., Popov, E., \& Peleckis, K. (2017). Modelling of Institutional Changes in Transition Countries - the Gap Between the Theory and Practice. Montenegrin Journal of Economics, 13(1), 125-140.

17. Gavurova, B., Vagasova, T., \& Kovac, V. (2016). Competitiveness Assessment of Slovak Republic Regions. European Financial System. 2016. 13th International Scientific Conference of the European Financial Systems. Edited by:Krajicek, J; Nesleha, J; Urbanovsky, KBrno, 2016, 175-184.

18. Chládková, H. (2015). Selected approaches to the business environment evaluation. Acta Universitatis Agriculturae et Silviculturae Mendelianae Brunensis, 63(2), 513-523. http://dx.doi. org/10.11118/actaun201563020515.

19. Investiční web. (2016). Světový žebříček konkurenceschopnosti vede Švýcarsko, Česko je 31. Co nám chybí, a v čem jsme naopak (relativně) silní? Available from http://www. investicniweb.cz/news-2016-9-28-zebricek-konkurenceschopnosti-vede-svycarsko-cr-je-31/.

20. Ivanová, E. (2017). Barriers to the development of SMEs in the Slovak Republic. Oeconomia Copernicana, 8(2), 255-272. https://doi.org/10.24136/oc.v8i2.16.

21. Kaur, D. \& Srivastava, S. (2017). Corporate debt restructuring and firm performance: a study of Indian firms. Serbian Journal of Management, 12(2), 271-281.

22. Kitching, J., Hart, M \& Wilson, N. (2015). Burden of benefit? Regulation as a dynamic influence on small business performance. International Small Business Journal, 33(2), 130-147.

23. Ključnikov, A. \& Popesko, B. (2017). Export and Its Financing in the SME Segment. Case Study From Slovakia. Journal of Competitiveness, 9(1), 20-35. https://doi.org/10.7441/ joc.2017.01.02.

24. Kljucnikov, A., \& Belas, J. (2016). Approaches of Czech entrepreneurs to debt financing and management of credit risk. Equilibrium. Quarterly Journal of Economics and Economic Policy, 11(2), 343-365. https://doi.org/10.12775/EQUIL.2016.016.

25. Kot, S. (2017). Funkcjonowanie małych i średnich przedsiębiorstw w kontekście zarządzania łańcuchem dostaw. Pržglad Organizacji, 11 (1), 3-11.

26. Kozubíková, L., Homolka, L., \& Kristalas, D. (2017). The Effect of Business Environment and Entrepreneurs' Gender on Perception of Financial Risk in the Sme Sector. Journal of Competitiveness, 9(1), 36-50. https://doi.org/10.7441/joc.2017.01.03. 
27. Körner, P., Kudrna, Z., \& Vychodil, O. (2002). Měření kvality podnikatelského prostř̌edí ve stř̌ední Evrope. Finance a úvěr, 52(12), 674-697.

28. Lakic, S. \& Draskovic, M. (2015). Implications of Institutional Dispositions of Neoliberalism. Montenegrin Journal of Economics, 11(2), 113-124.

29. Marinescu, C. (2013). Institutional Quality of the Business Environment: Some European Practices in a Comparative Analysis. Amfiteatru Economics, 15(33), 270-287.

30. Marinescu, C. \& Jora, O, D. (2013). Assessment on the institutional economics of corruption. Business and development in Romania, between formal and informal practices. Amfiteatru Economic, 15(7), 603-616.

31. Ohanyan G. \& Androniceanu, A. (2017). Evaluation of IMF program effects on employment in the EU. Acta Oeconomica, 67 (3), 311-332.

32. Petrenko, E., Iskakov, N., Metsyk, O., \& Khassanova, T. (2017). Ecosystem of entrepreneurship: risks related to loss of trust in stability of economic environment in Kazakhstan. Entrepreneurship and Sustainability Issues, 5(1), 105-115. https://doi.org/10.9770/ jesi.2017.5.1(8).

33. Pietrzak, M. B., Balcerzak, A. P., Gajdos, A., \& Arendt, L. (2017). Entrepreneurial environment at regional level: the case of Polish path towards sustainable socio-economic development. Entrepreneurship and Sustainability Issues, 5(2), 190-203. https://doi.org/10.9770/ jesi.2017.5.2(2).

34. Podnikatel'ská Aliancia Slovenska (2017). Slovensko sa posunulo v globálnom rebríčku, pomohlo viac leteckých liniek, mobilov, rýchlejš́ internet a zhoršenie iných. Available from: http://alianciapas.sk/category/pravidelneaktivity/ sprava oglobalnej konkurencieschopnosti/.

35. Podnikatel'ská Aliancia Slovenska. (2015). Index vnímania korupcie 2014. Available from: http://alianciapas.sk/wp-content/uploads/2015/06/05-TI-koment-2015.pdf.

36. Podnikatel.cz. (2013). Většina podnikatelů tráví papírováním celé dny, byrokracie se prý navíc zvyšuje. Available from: http://www.podnikatel.cz/clanky/vetsina-podnikatelu-travipapirovanim-nekolik-dni-byrokracie-se-navic-zvysuje/.

37. Sanusi, K. A., Meyer, D., \& Ślusarczyk, B. (2017). The relationship between changes in inflation and financial development. Polish Journal of Management Studies, 16 (2), 253-265.

38. Sinicakova, M., \& Gavurova, B. (2017). Single Monetary Policy versus Macroeconomic Fundamentals in Slovakia. Ekonomicky casopis, 65(2), 158-172.

39. Tonoyan, V., Strohmeyer, R., Habib, M. \& Perlitz, M. (2010). Corruption and entrepreneurship: How formal and informal institutions shape small firm behaviour in transition and mature market economics. Entrepreneurship theory and practice, 803-832.

40. Virglerova, Z., Homolka, L., Smrčka, L., Lazányi, K., \& Klieštik, T. (2017). Key determinants of the quality of business environment of SMEs in the Czech Republic. E \& M Ekonomie a Management, 20(2), 87-100. https://doi.org./10.15240/tul/001/2017-2-007.

41. Virglerova, Z., Dobes, K., \& Vojtovic, S. (2016). The Perception of the State Influence on Its Business Environment in the SMEs from the Czech Republic. Administratie si Management Public, 14 (26), 78-96. 
42. Vrchota, J. \& Rehor, P. (2017). Influence of strategies to determine the significance of the crisis by the managers of small and medium-sized enterprises. Serbian Journal of Management, $12(1), 53-63$.

43. Wruuck, P. (2015). The business environment in the eurozone. Deutsche Bank AG Deutsche Bank Research Frankfurt am Main Germany. Available at: https://www. dbresearch.com/PROD/DBR_INTERNET_EN-PROD/ PROD 00000000 00379559/ The_business_environment_in_the_eurozone\%3A_Why_it_i.pdf.

44. Social Science Statistics (2017). Z Score Calculator for 2 Population Proportions. Retrieved September 15, 2017 from: http://www.socscistatistics.com/tests/ztest/Default2.aspx.

45. Zizlavsky, O. (2016). Innovation performance measurement: research into Czech business practice. Economic Research-Ekonomska Istraživanja, 29(1), 816-838, https://doi.org/10.1080/ 1331677X.2016.1235983.

\section{Contact information}

Dr. Martin Cepel, Ph.D., MBA

Faculty of Economics and Business

Paneuropean University in Bratislava

Tematinska 10, 85105 Bratislava, Slovak Republic

E-mail:cepel@benzinol.com

Andrius Stasiukynas

Kazimieras Simonavicius University

Dariaus ir Gireno g. 21, Vilnius 02189, Lithuania

E-mail: andrius@snowarena.lt

Ing. Anna Kotaskova

Faculty of Economics and Business

Paneuropean University in Bratislava

Tematinska 10, 85105 Bratislava, Slovak Republic

E-mail:anna.kotaskova@gmail.com

Ing. Jan Dvorsky, Ph.D.

Tomas Bata University in Zlin

Faculty of Management and Economics

Mostni 5139, 76001 Zlín, Crech Republic

E-mail:jan.dvorsky5@gmail.com 